International Journal of

Environmental Research and

Public Health

ISSN 1660-4601

www.mdpi.com/journal/ijerph

Article

\title{
Inactivation of Selected Bacterial Pathogens in Dairy Cattle Manure by Mesophilic Anaerobic Digestion (Balloon Type Digester)
}

Christy E. Manyi-Loh ${ }^{1,2, *}$, Sampson N. Mamphweli ${ }^{1}$, Edson L. Meyer ${ }^{1}$, Anthony I. Okoh ${ }^{2}$, Golden Makaka $^{3}$ and Michael Simon ${ }^{1}$

1 Fort Hare Institute of Technology, University of Fort Hare, Alice Campus, Alice 5700, Eastern Cape Province, South Africa; E-Mails: smamphweli@ufh.ac.za (S.N.M.); emeyer@ufh.ac.za (E.L.M.); msimon@ufh.ac.za (M.S.)

2 Applied and Environmental Microbiology Research Group (AEMREG), Department of Biochemistry and Microbiology, University of Fort Hare, Alice Campus, Alice 5700, Eastern Cape Province, South Africa; E-Mail: aokoh@ufh.ac.za

3 Department of Physics, University of Fort Hare, Alice Campus, Alice 5700, Eastern Cape Province, South Africa; E-Mail: gmakaka@ufh.ac.za

* Author to whom correspondence should be addressed; E-Mail: cmanyi-loh@ufh.ac.za; Tel.: +27-738-324-268; Fax: +27-406-530-665.

Received: 21 May 2014; in revised form: 4 July 2014 / Accepted: 7 July 2014 /

Published: 14 July 2014

\begin{abstract}
Anaerobic digestion of animal manure in biogas digesters has shown promise as a technology in reducing the microbial load to safe and recommended levels. We sought to treat dairy manure obtained from the Fort Hare Dairy Farm by investigating the survival rates of bacterial pathogens, through a total viable plate count method, before, during and after mesophilic anaerobic digestion. Different microbiological media were inoculated with different serial dilutions of manure samples that were withdrawn from the biogas digester at 3, 7 and 14 day intervals to determine the viable cells. Data obtained indicated that the pathogens of public health importance were $90 \%-99 \%$ reduced in the order: Campylobacter sp. (18 days) < Escherichia coli sp. (62 days) $<$ Salmonella sp. (133 days) from a viable count of $10.1 \times 10^{3}, 3.6 \times 10^{5}, 7.4 \times 10^{3}$ to concentrations below the detection limit ( $\mathrm{DL}=10^{2} \mathrm{cfu} / \mathrm{g}$ manure), respectively. This disparity in survival rates may be influenced by the inherent characteristics of these bacteria, available nutrients as well as the stages of the anaerobic digestion process. In addition, the highest $p$-value i.e., 0.957 for
\end{abstract}


E. coli showed the statistical significance of its model and the strongest correlation between its reductions with days of digestion. In conclusion, the results demonstrated that the specific bacterial pathogens in manure can be considerably reduced through anaerobic digestion after 133 days.

Keywords: anaerobic digestion; dairy manure; enteropathogens; viable counts; regression models; South Africa

\section{Introduction}

Public health and environmental hazards linked to livestock practices and their generated wastes are becoming a major challenge of local, national and global concern. This is because the animal wastes are most times not disposed of properly as they are employed as soil conditioners and fertilizers on agricultural land to improve soil quality for better crop yield [1]. In particular, Grewal et al. [2] highlighted that most dairy wastes are largely stored as a liquid in a lagoon, or as solid manure, packed into piles after which they are employed for land application. However, in the liquid form, manure has the potential to contaminate soil and surface water bodies through infiltration and/or runoff and present noxious odors. Livestock manure usually contains a diverse group of microorganisms, including bacteria, protozoa and viruses that can cause infections in humans and/or animals if not properly managed and contained [3]. Bacteria that have been well documented in manure include Salmonella sp., E. coli and Campylobacter species which are associated with human gastrointestinal infections, therefore manure is a potential source of contamination [4].

Clearly, to assess the threat posed by the aforementioned bacterial pathogens in the manure, the levels/survival rates of these pathogens need to be evaluated, which in turn determines the potential of the manure to cause contamination/infection [5]. This information can be obtained by viable plate count methods to monitor the duration of survival of pathogenic microorganisms shed in the animal wastes [6]. The survival rates of the bacterial pathogens reported in animal wastes can be influenced by the physico-chemical characteristics of the wastes and microbial competition. More elaborately, the level of these pathogens in manure is influenced by the physicochemical characteristic of the manure, which is dependent on the weather and soil conditions (i.e., geographical location) [7] and also influenced by other factors such as age and species of the animal, diet and collection and storage facilities of the farms $[8,9]$.

Nevertheless, the animal wastes can be treated via biological, physical and chemical methods in order to reduce or control the pathogenic microbes [10]. Moreover, the aforementioned pathogen control methods have been evaluated elsewhere and reports indicated that most mesophilic biological treatment processes are not likely to reduce pathogen levels by $90 \%-99 \%$. However, to the best of our knowledge, no available data exist in literature on any of these methods being implemented by any dairy farm in the Eastern Cape Province of South Africa for the purpose of pathogen control. More especially, since Lutge and Standish [11] reported that very few on-farm digesters are available in South Africa and the biogas digesters were principally built and installed in the Western and Kwa-Zulu Natal 
provinces of the country [12]. In addition, the information about the potential environmental and health risks related to animal manure is obvious $[13,14]$.

Against this background, this study sought to determine the reduction of E. coli, Salmonella and Campylobacter species by investigating their viable counts before, during and after mesophilic anaerobic digestion of dairy manure obtained from the Fort Hare Dairy Farm, Alice, Eastern Cape Province of South Africa for the purpose of reducing bacterial pathogens as one of the facets in the overall sanitization of the environment. In addition, regression models were developed to emphasize the relationship between the logarithmic bacterial count and the duration of digestion (retention time).

\section{Materials and Methods}

\subsection{Experimental Set Up}

A balloon digester was enclosed within a concrete structure $\left(8 \mathrm{~m}^{3}\right)$ divided originally into three compartments: feeding tank of $83 \mathrm{~cm}$ height, $89 \mathrm{~cm}$ width and $95 \mathrm{~cm}$ length; bioreactor tank of $3.25 \mathrm{~m}$ height and $2 \mathrm{~m}$ width and lastly, the effluent tank (Figure 1). It was installed within the concrete structure because it is highly susceptible to physical damage and difficult to repair [12]. The balloon is the airtight chamber within which the anaerobic degradation of the dairy waste was conducted as both ends of the balloon were sealed with concrete to the influent chamber and the other to the effluent chamber. In addition, four temperature sensors (two sensors embedded at different levels in the slurry, one sensor at the biogas space and the last sensor within the concrete chamber housing the balloon digester (ambient) were externally connected to the Hobo U12, 4-channel data logger which was configured to log, the daily slurry, biogas and the ambient temperature profiles every $30 \mathrm{~min}$. Also, a gas analyzer harboring methane and carbon dioxide gas sensors was connected through tubing incorporating a flow transducer. As the biogas flows through the tubing, the flow transducer measured the flow rate of the biogas into the gas analyzer, where the percentages composition of methane and carbon dioxide (important greenhouse gases) were detected.

Accordingly, the balloon digester was charged with a homogeneous mixture of dairy manure and water in the ratio 1:1 [15]. The mixing ratio was determined by the moisture content of the dairy manure procured from the Fort Hare Dairy Farm. The digester was batch operated under mesophilic conditions for six months.

\subsection{Microbial Analysis}

Total viable counts of bacterial colonies on solidified agar plates were used as a measure of the level of particular bacterial cells present in the manure. Initial bacterial counts in the original fresh manure were evaluated before the digestion process. In addition, during digestion, samples were withdrawn from the digester, every three, seven and fourteen day interval for continuous evaluation of bacterial counts. Each withdrawn sample was aseptically collected into sterile centrifuge tubes and transported on ice to the laboratory. Samples required for the determination of Campylobacter and Salmonella counts were introduced into the typtic soy broth before transportation to the laboratory [16]. 
Figure 1. Designed layout of constructed balloon digester with the data acquisition system.

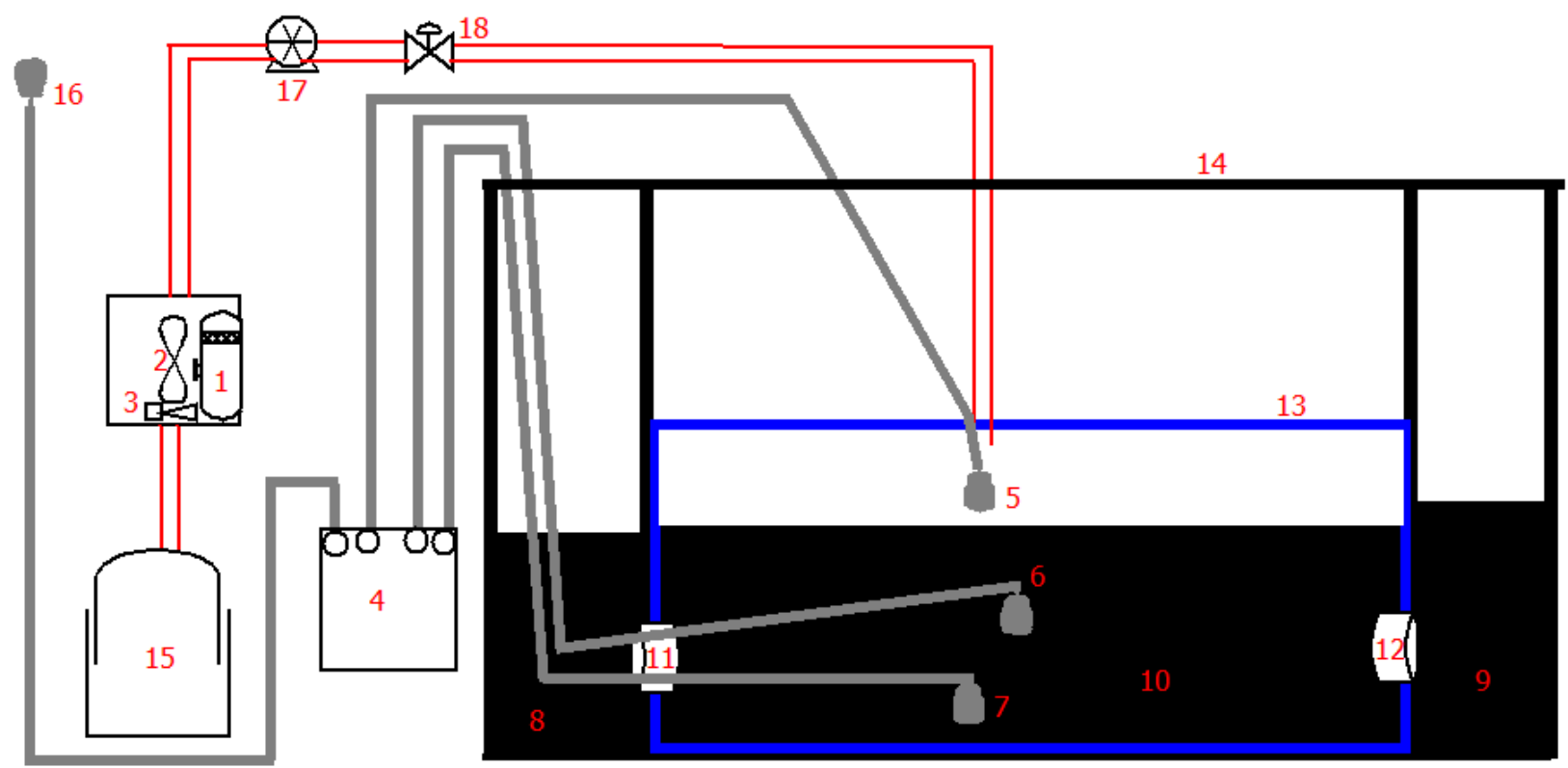

Notes: 1, Campbell data logger; 2, Gas analyser; 3, Flow transducer; 4, Hobo data logger; 5, Produce gas temperature sensor; 6, Intermediate slurry temperature sensor; 7, Bottom slurry temperature sensor; 8, Chamber inlet; 9, Chamber outlet; 10, Slurry trap inside balloon; 11, Slurry inlet; 12, Slurry outlet; 13, Balloon digester; 14, Insulation cover; 15, Gas collection chamber; 16, Ambient temperature sensor; 17, Pump; 18, Control valve

Evaluation of the total bacterial counts was conducted as per the method of Poudel et al. [3]. Briefly, $1 \mathrm{~g}$ of each sample was serially diluted tenfold in $9 \mathrm{~mL}$ of sterile physiological saline. Dilutions from $10^{-1}$ to $10^{-5}$ were spread in triplicates on different microbiological media, including Salmonella/Shigella agar (Conda, Madrid, Spain), E. coli chromogenic agar (Conda), and blood free Campylobacter agar (mCCDA, Conda) to obtain total Salmonella sp., total E. coli and total Campylobacter sp. counts, respectively. All inoculated plates were incubated at $37{ }^{\circ} \mathrm{C}$ for $24 \mathrm{~h}$, except that the plates for total Campylobacter counts were incubated at $42{ }^{\circ} \mathrm{C}$ under microaerophilic conditions provided by a gas generating kit (BR0038, Oxoid, Basingstoke, UK) for 24-48 h [17]. After incubation, the number of emergent colonies on each plate was counted taking into considerations their morphological and cultural characteristics [18,19]. Each value was recorded on a table and it represented the mean of triplicate spreading [20]. Of great significance, Sutton [21] recommended that where no colony was counted on the plate, the count should be recorded as less than the detection limit and the day of digestion was considered as the survival period of the pathogen. As indicated in this study, $10^{-1}(1: 10)$ dilution produced no colonies on plates, the number of counts was $<10 \mathrm{cfu} / \mathrm{g}$. Furthermore, after the 10-fold dilution, we plated just $100 \mu \mathrm{L}$ (not a full $\mathrm{mL}$ ) of 1:10 dilution. In effect, an additional $10^{-1}$ dilution $(100 \mu \mathrm{L} / 1000 \mu \mathrm{L})$. Therefore, the total effective dilution was $10^{-1} \times 10^{-1}=10^{-2}$. Hence, the detection limit was $10^{2} \mathrm{cfu} / \mathrm{g}$ manure. 


\subsection{Statistical Analysis}

Data were analyzed and a linear regression model was developed between log bacterial load and days of anaerobic digestion using Matlab statistical software package (Student version, R2012a, The MathWorks, Inc., Natick, MA, USA).

\section{Results}

Clearly, Campylobacter sp., Escherichia coli and Salmonella sp. were present in the manure with initial viable counts of $10.1 \times 10^{3}, 3.6 \times 10^{5}$ and $7.4 \times 10^{3} \mathrm{cfu} / \mathrm{g}$, respectively, whose equivalence in logarithmic values were 4, 5.6 and $3.9 \mathrm{cfu} / \mathrm{g}$, respectively. These bacteria were identified and confirmed by their morphological and culture characteristics. In addition, the viable counts of the bacteria in the manure before, during and after anaerobic digestion were converted to logarithmic values. These logarithmic values were plotted against retention time in days as shown in Figure $2 \mathrm{a}-\mathrm{c}$ to reveal their relationship. The bacterial load (log viable counts) of Campylobacter sp., E. coli and Salmonella sp. decreased with an increase in the number of days from 4, 5.6, and 3.9 to $<$ detection limit, respectively, through a period of 18,62 and 133 days, respectively. These different numbers of days represented the days in which no growth was observed from the $10^{-1}$ dilution of the sample used for the isolation of each of the bacterium. The survival rate in days was therefore in the sequence; Campylobacter sp. $<$ E. coli $<$ Salmonella sp.

Figure 2. (a) Reduction of Campylobacter sp. counts with retention time. (b) Reduction of E. coli counts with retention time. (c) Reduction of Salmonella sp. counts with retention time.

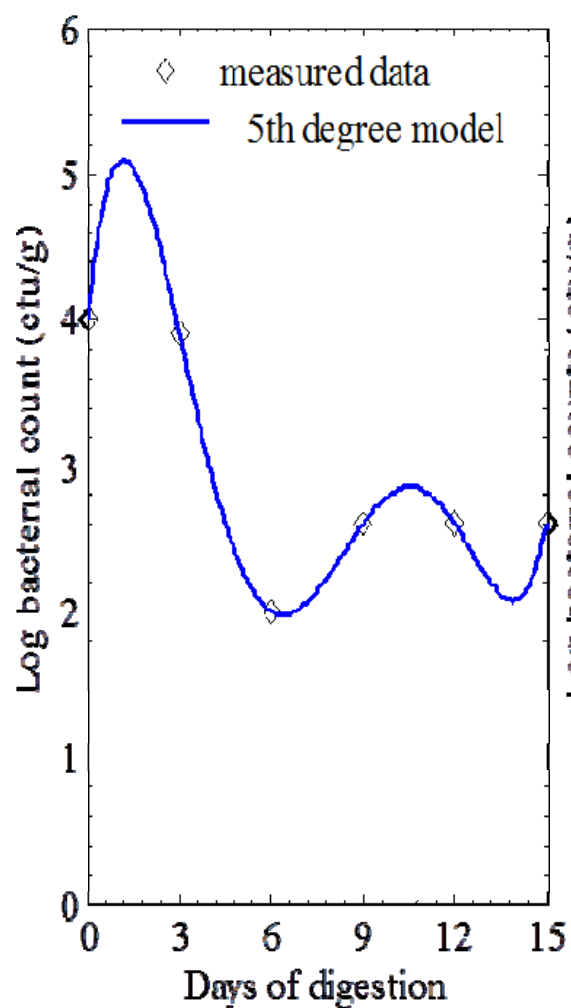

(a)

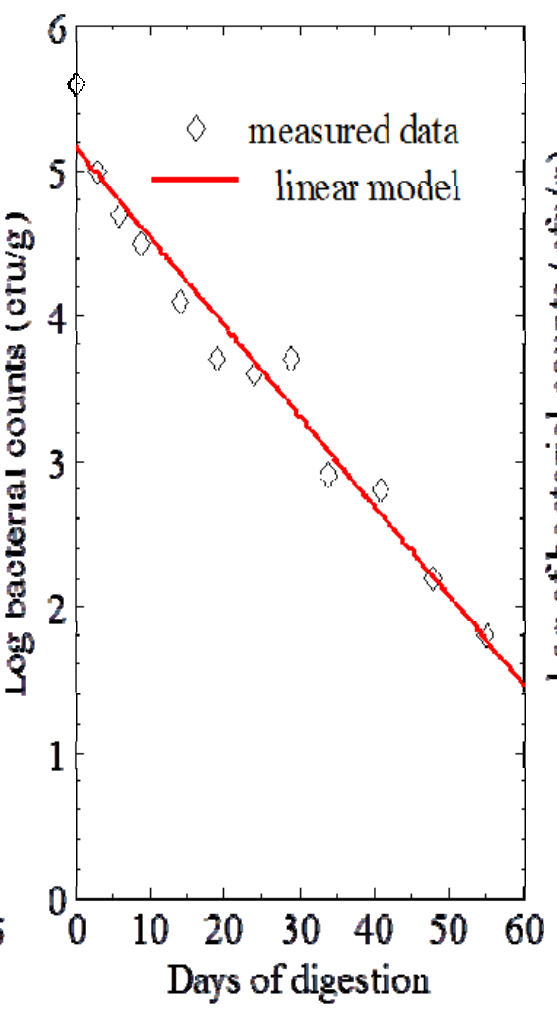

(b)

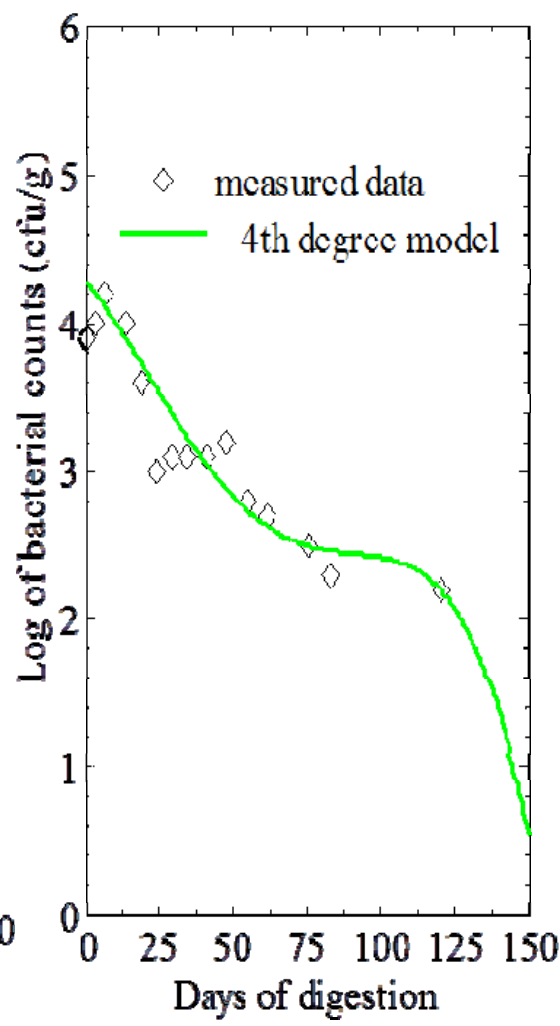

(c) 
On the other hand, a $1 \log$ reduction (90\%) of E. coli and Campylobacter sp. was obtained during the period of digestion whilst Salmonella sp. were reduced by $2 \log (99 \%)$ between day 9 and 14 and $1 \log$ reduced throughout the rest of the process.

The relationship between log bacterial counts and the days of digestion are shown in Table 1 . The regression models were developed wherein the last entry on the data set $(<100 \mathrm{cfu} / \mathrm{g}$, the detection limit) was excluded in order to maintain data integrity. These models indicated the kind of relationship and the highest $p$-value of 0.957 noted the statistical significance/degree of validity presented by the regression model incorporating the $\log$ reduction of $E$. coli with days of digestion.

Table 1. Regression model of log bacterial count with retention time (days).

\begin{tabular}{cccccccccc}
\hline Bacteria & Log of Count & $\mathbf{X}^{\mathbf{5}}$ & $\mathbf{X}^{\mathbf{4}}$ & $\mathbf{X}^{\mathbf{3}}$ & $\mathbf{X}^{\mathbf{2}}$ & $\mathbf{X}$ & Constant & $\boldsymbol{R}^{\mathbf{2}}$ & $\boldsymbol{p}$-value \\
\hline ERN & $\mathrm{Y}$ & 0 & 0 & 0 & 0 & -0.61 & 5.2 & 0.976 & 0.957 \\
SMN & $\mathrm{Y}$ & 0 & $-4.5 \times 10^{-8}$ & $1 \times 10^{-5}$ & $-5.1 \times 10^{-4}$ & -0.023 & 4.3 & 0.960 & 0.773 \\
CPL & $\mathrm{Y}$ & $3.8 \times 10^{-3}$ & -0.015 & 0.21 & -1.2 & 2.1 & 4 & 0.991 & 0.723 \\
\hline
\end{tabular}

Notes: ERN, Escherichia coli; SMN, Salmonella sp.; CPL, Campylobacter sp.; Y = log the bacterial count and $\mathrm{X}=$ days of digestion.

\section{Discussion}

Theoretically, under normal circumstances and favorable conditions, a bacterium tends to thrive in the environment where it occurs by first adapting to the environment and subsequently growing, multiplying or dividing by binary fission. Later, when the growth of these bacterial cells becomes limited, they stop dividing until they eventually die, causing a decline in their population due to lack of space, exhaustion of nutrients and accumulation of toxic waste products. Factors such as moisture, temperature, and $\mathrm{pH}$, nutrients (both macro- and micronutrients) are necessary for microbial survival [22]. However, this pattern of growth is often not represented practically in the environment. Specifically, the decay rate of viable bacterial in a biogas plant can be influenced by many factors including temperature, treatment time, $\mathrm{pH}$, volatile fatty acids, batch or continuous feeding process, bacterial species and available nutrients [23].

For farm-based purposes, we investigated the significance of using an anaerobic digester to sanitize dairy cattle manure prior to further usage. This was achieved by monitoring the fate of selected zoonotic pathogens such as Campylobacter sp., Salmonella sp. and Escherichia coli by a viable plate count assay. The viable counts revealed the viability of these bacteria with time and ranged from $10.1 \times 10^{3}, 3.6 \times 10^{5}$, and $7.4 \times 10^{3}$ to concentrations below the detection limit $(<100 \mathrm{cfu} / \mathrm{g})$, respectively. We noted that the survival rates of the aforementioned pathogens were in the order; Campylobacter sp. (18 days) < Escherichia coli (62 days) < Salmonella sp. (133 days) as shown in Figure 2a-c. However, this contradicts the finding of Strauch [7] who reported that the inactivation of pathogens in manure is reliant on the initial level of these pathogens present. Accordingly, E. coli with the highest concentration of $3.6 \times 10^{5} \mathrm{cfu} / \mathrm{g}$, determined in manure before the anaerobic digestion treatment, was expected to take the longest time to be inactivated. Contrarily, in this study, Salmonella $\mathrm{sp}$. with the least concentration of $7.4 \times 10^{3} \mathrm{cfu} / \mathrm{g}$ had the longest survival period.

Regarding the log reduction of these enteropathogens during their survival periods, a 1 log reduction of both E. coli and Campylobacter species was achieved, indicating a 90\% killing rate of these 
bacterial cells during digestion. Contrarily, the decay rate of Salmonella cells was not consistent; a $2 \log$ reduction of these cells occurred between day 9 and 14 and a $1 \log$ reduction throughout the rest of the process representing a killing rate of $90 \%$ to $99 \%$ during the anaerobic degradation process. Despite the magnitude of the log reduction, these small reductions in the prevalence or levels of these zoonotic pathogens in manure being treated anaerobically would significantly lower the risk of pathogen dissemination through land application/spreading of manures as large quantities of wastes are often generated [5]. In addition, this method of treatment generated biogas; an alternative energy source which could be used for heating and or converted to electricity by combined heat and power plants for other purposes. Moreover, the greenhouse gases (methane and carbon dioxide) were confined within the digester thus prevents global warming [24].

Although, we measured some physicochemical characteristics of our manure sample that are relevant for anaerobic digestion, and which also support the growth of these bacteria, literature has it that cattle manure is well balanced nutritionally with a $\mathrm{C}: \mathrm{N}$ ratio of between 20 and 30 and is a good source of nitrogen; all of which are necessary for the growth of anaerobic microorganisms [25]. In addition, Sahlström [23] in his findings noted the variation in the survival rates between bacteria and attributed it to the differences in bacterial species (type) and available nutrients. Consequently, as shown in Figure $2 \mathrm{a}-\mathrm{c}$, the duration of survival of these bacteria (i.e., 18, 62 and 133 days for Campylobacter sp., E. coli and Salmonella sp., respectively) could be influenced by the characteristics endowed to each bacteria even though they belong to the same domain, bacteria. It is obvious that being classified under different genus and species inferred they might possess different phenotypes and genotype characteristics, thus they might vary in the environmental requirements necessary for their growth [26,27]. Furthermore, the growth of these bacteria could also be affected by the different stages that are involved in the degradation process of the organic matter under anaerobic conditions. This could simply be explained by the fact that the decomposition of any organic material entails different degradation steps that requires microorganisms which may be specific for each stage, thus resulting in varying end products throughout the process [27].

More elaborately, the trend in the survival rate might possibly be explained by the fact that Campylobacter sp. is microaerophilic in nature [28] thus subjecting these cells under strict anaerobic conditions would cause them to die out quickly after a while (in this case 18 days) as compared to the other bacterial cells that are facultative in nature (i.e., can survive both in the presence and absence of oxygen). Moreover, the early phases of anaerobic degradation process produce $\mathrm{CO}_{2}$ and a decrease in $\mathrm{pH}$ (due to the level of volatile fatty acids) [29]. This may suggest that Campylobacter cells were most probably sustained under such conditions and eventually die out as the process progresses. Not withstanding, Bui et al. [30] reported that the ability of Campylobacter coli to survive in manure and the capability to cause human infection are not clearly comprehended.

Furthermore, Escherichia coli and Salmonella sp. belong to the group Enterobacteriaceae that are responsible for the deconstruction of biomass during the first step in the bioconversion of carbohydrates to methane, as active fermenters that are anaerobic in nature [31-33]. This may suggest that the prevailing anaerobic conditions under which decomposition was conducted, supported these organisms for a further length of time as opposed to Campylobacter species. However, the overall results of the rate of killing of the bacteria (log reduction) contradict earlier reports by Côté et al. [20], 
Poudel et al. [3] and Harrison et al. [34] who reported the reduction of these enteropathogens by $97.94 \%$ to $100 \%, 99.999 \%$ and $99 \%$ to $100 \%$, respectively.

These contradictory results are expected because the metabolic activities of specific organisms during anaerobic digestion could be influenced by the chemical composition of the wastes, environmental factors (temperature), digester operating conditions (batch or continuous mode) as well as the type of digester used $[23,35]$. Moreover, the physicochemical properties of wastes are dependent on the weather and soil conditions that influence the feed (vegetation) of these animals and this might vary from one geographical location to the other added to the fact that the overall microbial species also vary with farm practices and the aforementioned environmental conditions.

In addition, from the above Figure $2 \mathrm{a}-\mathrm{c}$, the regression lines were the generated models. From these, it can be depicted that the log of bacterial counts reduced with an increase in digestion time (number of days). However, the rate of reduction of the bacteria was in the order Campylobacter sp. $<$ E. coli $<$ Salmonella; even though, it was reported that the inactivation of microbial pathogens is subject to the initial counts of the specific microbes present in the wastes [7]. Furthermore, the equations for the different models are as shown in Table 1 and these regression models were used to forecast the log bacterial count reduction with time. The linear regression model showing the $\log$ reduction of $E$. coli with days of digestion has the highest $p$-value of 0.957 thus it is statistically significant indicating that the experimental data fits well into the model and $97.6 \%$ of the data variability can be interpreted by its regression model therefore, a higher validity of the model.

\section{Conclusions}

Anaerobic digestion technology was shown as a promising technology for the reduction of bacterial pathogens occuring in dairy manure as one of the facets in the overall process of sanitizing the environment for better public health safety. The microbial load was grossly reduced and the reduction of bacterial pathogen depended on the days of digestion. This indicates the need for biogas digesters on farms to recover biogas, a cheaper source of energy from the readily available animal manure and in addition aid in sanitization. Furthermore, the information generated by the interpretation of data recorded in this study, provides the basis for the development of guidelines essential for good and suitable plans for manure handling by farmers as they can be correlated with the farm practices thereby helping the farmers in proper management.

\section{Acknowledgments}

We are grateful to Claude Leon Foundation, South Africa for financial support. Special thanks to the Fort Hare Institute of Technology for the purchase of the materials utilized in this study and also to Makhozanele David May and Filipu Yelton Ndlovu for technical assistance.

\section{Author Contributions}

Christy E. Manyi-Loh conceived and designed the study. She executed the work and also analyzed, and interpreted the data as well as drafted the manuscript. Edson L. Meyer, Sampson N. Mamphweli 
and Golden Makaka participated in the conception and design of the study. Anthony I. Okoh participated in designing of the study and critically revised the manuscript for important intellectual content. Michael Simon critically revised the manuscript for important intellectual content. All the authors read, edited and approved the final version of the manuscript for publication.

\section{Conflicts of Interest}

The authors declare no conflict of interest.

\section{References}

1. Grant, S.; Marshalleck, A. Energy Production and Pollution Mitigation from Broilers Houses on Poultry Farms in Jamaica and Pennsylvania. Int. J. Serv. Learn. Eng. 2008, 3, 41-52.

2. Grewal, S.K.; Rajeev, S.; Sreevatsan, S.; Michel, F.C., Jr. Persistence of Mycobacterium avium subsp. Paratuberculosis and other zoonotic pathogens during simulated composting, manure packing and liquid storage of dairy manure. Appl. Environ. Microbiol. 2006, 72, 565-574.

3. Poudel, R.M.; Joshi, D.R.; Dhakal, N.R.; Karki, A.B. Anaerobic digestion of sewage sludge mixture for the reduction of indicator and pathogenic microorganisms. Sci. World 2010, 8, 47-50.

4. Vanselow, B.A.; Hornitzky, M.A.; Bailey, G.D. Intensification of cattle production increases the risk of zoonotic campylobacteriosis. In Proceedings of the 11th International Symposium on Veterinary Epidemiology and Economics, Cairns, Australia, 6-11 August 2006.

5. Hutchison, M.L.; Walters, L.D.; Avery, S.M.; Munro, F.; Moore, A. Analyses of livestock production, waste storage and pathogen levels and prevalences in farm manures. Appl. Environ. Microbiol. 2005, 71, 1231-1236.

6. Nicholson, F.A.; Groves, S.J.; Chambers, B.J. Pathogen survival during livestock manure storage and following land application. Bioresource Technol. 2005, 96, 135-143.

7. Strauch, D. Survival of pathogenic micro-organisms and parasites in excreta, manure and sewage sludge. Rev. Sci. Tech. Off. 1991, 10, 813-846.

8. Hess, T.F.; Grdzelishvili, I.; Sheng, H.Q.; Hovde, C.J. Heat inactivation of E. coli during manure composting. Compost Sci. Utilization 2004, 12, 314-322.

9. Martin, H. Manure composting as a pathogen reduction strategy. In Agricultural Engineering and Animal Science. Factsheet; Ministry of Agriculture and Food: Guelph, ON, Canada, 2005.

10. Čempírková, R.; Šoch, M. The analysis of real microbiological risks for dissociated slurry. Agric. Trop. Subtrop. 2007, 40, 164-171.

11. Lutge, B.; Standish, B. Assessing the potential for electricity generation from animal waste biogas on South African farms. Agrekon: Agric. Econ. Res. Policy Pract. South. Afr. 2013, 52, 1-24.

12. Mukumba, P.; Makaka, G.; Mamphweli, S.; Simon, M.; Meyer, E. An insight into the status of biogas digesters technologies in South Africa with reference to the Eastern Cape Province. Fort Hare Pap. 2012, 19, 5-29.

13. Gerba, C.P.; Smith, J.E., Jr. Sources of pathogenic microorganisms and their fate during land application of wastes. J. Environ. Qual. 2005, 34, 42-48. 
14. Manyi-Loh, C.E.; Mamphweli, S.N.; Meyer, E.L.; Okoh, A.I.; Makaka, G.; Simon, M. Micobial anaerobic digestion as an approach to the decontamination of animal wastes in pollution control and generation of renewable energy. Int. J. Environ. Res. Public Health 2013, 10, 4390-4417.

15. Yongabi, K.A.; Harris, P.L.; Lewis, D.M.; Agho, M.O. Preliminary study on the effect of anaerobically digested cow dung slurry on the antimicrobial activity of three medicinal plants. Afr. J. Micobiol. Res. 2009, 3,168-174.

16. Srijan, A.; Bodhidatta, L.; Mason, C.J.; Bunyarakyothin, G.; Jiarakul, W.; Vithayasai, N. Field evaluation of a transport medium and enrichment broth for the isolation of Campylobacter species from human diarrheal stool samples. Open J. Med. Microbiol. 2013, 3, 48-52.

17. Nyachoti, C.M.; Omogbenigun, F.O.; Rademacher, M.; Blank, G. Performance responses and indicators of gastrointestinal health in early-weaned pigs fed low-protein amino acid-supplemented diets. J. Anim. Sci. 2006, 84, 125-134.

18. Cheesbrough, M. Part 2: Microbiology. In District Laboratory Practice in Tropical Country; Cambridge University Press: Cambridge, UK, 2000.

19. Campylobacter Jejuni and Campylobacter coli; In OIE Terrestrial Manual; World Organization for Animal Health: Paris, France, 2008; pp. 1185-1191.

20. Côté, C.; Massé, D.I.; Quessy, S. Reduction of indicator and pathogenic microorganisms by psychrophilic anaerobic digestion in slurries. Bioresour. Technol. 2006, 97, 686-691.

21. Sutton, C. Accuracy of Plate Counts. Available online: http://www.microbiol.org/wp-content/ uploads/2010/07/Sutton.jvt_.2011.17_3.pdf(accessed on 9 July 2014).

22. Willey, J.; Sherwood, L.M.; Woolverton, C.J. Microbial growth. In Prescott's Microbiology, 8th ed.; McGraw-Hill Companies Inc.: New York, NY, USA, 2011; pp. 162-189.

23. Sahlström, L. A review of survival of pathogenic bacteria in organic waste used in biogas plants. Bioresour. Technol. 2003, 87, 161-166.

24. Ramanathan, V.; Feng, Y. Air pollution, greenhouse gases and climate change: Global and regional perspectives. Atmos. Environ. 2009, 43, 37-50.

25. Strik, D.P.B.T.B.; Domnanovich, A.M.; Holubar, P.A. A pH-based control of ammonia in biogas during anaerobic digestion of artificial pig manure and maize silage. Process Biochem. 2006, 41, $1235-1238$.

26. Willey, J.; Sherwood, L.M.; Woolverton, C.J. Microbial Taxonomy and Evolution of Diversity. In Prescott's Microbiology, 8th ed.; McGraw-Hill Companies Inc.: New York, NY, USA, 2011; pp. 446-472.

27. Babaee, A.; Shayegan, J. Effects of Organic Loading Rates (OLR) on production of methane from anaerobic digestion of vegetable waste. In Proceedings of the World Renewable Energy Congress, Linköping, Sweden, 8-13 May 2011; pp. 411-417.

28. Anunputtikul, W.; Rodtong, S. Laboratory Scale Experiments for Biogas Production from Cassava Tubers. In Proceedings of the Joint International Conference on "Sustainable Energy and Environment (SEE)”, Hua Hin, Thailand, 1-3 December 2004; pp. 238-243.

29. Bui, X.T.; Woff, A.; Madsen, M.; Bang, D.D. Fate and survival of Campylobacter coli in swine manure at various temperatures. Front. Microbiol. 2011, 2, doi:10.3389/fmicb.2011.00262. 
30. Carbone, S.R.; da Silva, F.M.; Tavares, C.R.G.; Dias Filho, B.P. Bacterial population of a two-phase anaerobic digestion process treating effluent of cassava starch factory. Environ. Technol. 2002, 23, 591-597.

31. Blumer-Schuette, S.E.; Kataeva, I.; Westpheling, J.; Adams, M.W.W.; Kelly, R.M. Extremely thermophilic microorganisms for biomass conversion: Status and prospects. Curr. Opin. Biotechnol. 2008, 19, 210-217.

32. Wirth, R.; Kovács, E.; Maròti, G.; Bagi, Z.; Rakhely, G.; Kovács, K.L. Characterization of a biogas-Producing microbial community by short-read next generation DNA sequencing. Biotechnol. Biofuels 2012, 5, doi:10.1186/1754-6834-5-41.

33. Harrison, J.H.; Gay, J.M.; McClanahan, R.; Whitefield, E.; Saunders, O.; Fortuna, A.M. Managing Manure to Minimize Environmental Impact. In Proceeding of the 2011 Midwest Manure Summit, Lambeau Field, Green Bay, WI, USA, 15-16 February 2011.

34. Cha, G.-C.; Chung, H.-K.; Kim, D.-J. Characteristics of temperature change on the substrate degradation and bacterial population in one-phase and two-phase anaerobic digestion. Environ. Eng. Res. 2001, 6, 99-108.

35. Demirel, B.; Scherer, P. The roles of acetotrophic and hydrogenotrophic methanogens during anaerobic conversion of biomass to methane: A review. Rev. Environ. Sci. Biotechnol. 2008, 7 , 173-190.

(C) 2014 by the authors; licensee MDPI, Basel, Switzerland. This article is an open access article distributed under the terms and conditions of the Creative Commons Attribution license (http://creativecommons.org/licenses/by/3.0/). 